\title{
Lack of association between 4 key TNF-alpha promoter polymorphisms and hepatitis $C$ virus infection in a population of Egyptian patients
}

\author{
Ahmed M. Ghoneim*(i)
}

Zoology Department, Faculty of Science, Damietta University, New Damietta, Egypt

\section{Correspondence}

Ahmed M. Ghoneim, Zoology Department, Faculty of Science, Damietta University, New Damietta, Egypt

Email: am_ghoneim@du.edu.eg History

- Received: Mar 21, 2019

- Accepted: May 20, 2019

- Published: May 30, 2019

DOI :

https://doi.org/10.15419/bmrat.v6i5.542

\section{Check for updates}

\section{Copyright}

(c) Biomedpress. This is an openaccess article distributed under the terms of the Creative Commons Attribution 4.0 International license.

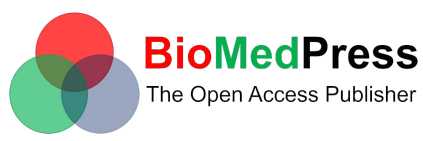

\begin{abstract}
Introduction: With 170 million chronic hepatitis C virus (HCV) cases worldwide, HCV is considered a major life-threatening pathogen. HCV is a crucial causative of liver cirrhosis and hepatocellular carcinoma. Tumor necrosis factor- $\alpha$ (TNF- $\alpha$ ) is thought to be a mediator in the development of viral hepatitis. Because HCV is epidemic in Egypt, this study aimed to characterize the distribution of TNF- $\alpha$ gene promoter polymorphisms and their relation to TNF- $\alpha$ expression in HCV patients. Methods: Four promoter polymorphisms; - 1031T/C, -863C/A, -857C/T, and -308G/A, were studied by restriction fragment length polymorphism in a population of Egyptian HCV patients. Results: Compared to healthy subjects, none of these polymorphisms were associated with HCV infection. The wild-type $-1031 \mathrm{~T},-863 \mathrm{~A},-857 \mathrm{C}$, and $-308 \mathrm{G}$ alleles were highly prevalent in the studied population. Sequencing the promoter region spanning the four studied polymorphisms in some subjects did not reveal any difference in the nucleotide variance pattern, compared with the TNF- $\alpha$ reference sequence. Relative TNF- $\alpha$ mRNA expressions in HCV patients and healthy subjects were statistically indifferent. Conclusion: Since previous studies confirmed an increase in TNF- $\alpha$ level in case of viral infections, this study focuses on mechanisms of post-transcriptional and posttranslational modifications of TNF- $\alpha$ gene in HCV patients, which decode the genetic factors linked to HCV infection and severity.

Key words: Polymorphism, Expression, TNF- $\alpha$, Cytokine, Hepatitis C Virus
\end{abstract}

\section{INTRODUCTION}

The Hepatitis $\mathrm{C}$ virus (HCV) is the major cause of liver cirrhosis and hepatocellular carcinoma (HCC), which is the most common causative of liver transplantation in several countries ${ }^{1}$. Globally, about 170 million people are chronically infected with $\mathrm{HCV}^{2}$. Chronic liver inflammation develops by the aid of various mediators, which may act as cofactors in carcinogenesis $^{3}$. Among these mediators, the tumor necrosis factor- $\alpha$ (TNF- $\alpha)$ is a critical pathogenic mediator in the development of viral hepatitis. TNF- $\alpha$ is required for the propagation of liver cells in case of liver damage. It also mediates hepatotoxicity ${ }^{4}$.

Various types of cells produce TNF- $\alpha$. To become biologically active, it binds to two target cell receptors: TNFR 1 and TNFR $2^{5}$. TNF- $\alpha$-encoding gene is located on chromosome 6 in the class III region of the major histocompatibility complex. Its promoter region contains several polymorphisms, the most common of which are $-1031 \mathrm{~T} / \mathrm{C},-863 \mathrm{C} / \mathrm{A}$, $-857 \mathrm{C} / \mathrm{A},-376 \mathrm{G} / \mathrm{A},-308 \mathrm{G} / \mathrm{A}$, and $-238 \mathrm{G} / \mathrm{A}$. Some of these genetic polymorphisms (1031T/C, -376G/A,
$-308 \mathrm{G} / \mathrm{A}$, and $-238 \mathrm{G} / \mathrm{A})$ were found to affect TNF$\alpha$ expression levels ${ }^{6}$.

TNF- $\alpha-308 \mathrm{G} / \mathrm{A}$ polymorphism was linked to the pathogenesis and advancement of chronic hepatitis $\mathrm{C}$ $(\mathrm{CHC})^{7,8}$. Dogra et al. ${ }^{9}$ reported a significant association between TNF- $\alpha-308$ GG genotype and HCV infection in patients when compared with healthy individuals. Dai et al. ${ }^{10}$ reported that detecting of TNF- $\alpha-308 \mathrm{~A}$ allele before administering combination therapy might be useful for predicting the treatment response, especially in difficult-to-treat $\mathrm{HCV}$ patients.

TNF- $\alpha$ was reported as a carcinogenesis cofactor ${ }^{3}$ with a potential role in cancer pathogenesis ${ }^{11}$, and its level elevated in HCC patients ${ }^{12}$. According to Yang et al. ${ }^{11}$ meta-analysis, TNF- $\alpha-308 \mathrm{G} / \mathrm{A}$ polymorphism was assumed to confer a higher risk of HCC, especially in the Asian population. Xiao et al. ${ }^{13}$ metaanalysis revealed that increased HBV-HCC risk was associated with TNF- $\alpha-308$ AA and TNF- $\alpha-238$ AA, and with TNF- $\alpha-863 \mathrm{CA}$ genotypes. In some Chinese populations, TNF- $\alpha-308 \mathrm{G} / \mathrm{A}$ polymorphism was associated with HCC susceptibility ${ }^{14}$. 
In Egypt, $\mathrm{HCV}$ is an epidemic with a prevalence of $14.7 \%{ }^{15}$. Approximately $75-85 \%$ of $\mathrm{HCV}$-infected persons will progress to chronic infection and risk developing $\mathrm{HCC}^{1}$. This study aims to evaluate the distribution of TNF- $\alpha$ gene polymorphisms in HCVinfected patients in the Egyptian population and explore whether any of these polymorphisms are linked to HCV-infection and TNF- $\alpha$ expression.

\section{SUBJECTS - METHODS}

\section{Subjects}

Blood samples were collected from 100 subjects (50 HCV RNA-positive patients and 50 healthy subjects). The study was ethically authorized by our institute's board (No. 5/2/2/1 and 5/2/2/8), and all subjects gave their written consent before samples were collected. All HCV-positive patients were Hepatitis B virus (HBV)-negative and rheumatoid factor-negative, and the healthy subjects were negative for both of $\mathrm{HCV}$, $\mathrm{HBV}$, and rheumatoid factors.

\section{Genotyping}

Genomic DNA was extracted from blood samples by Gene JET ${ }^{T M}$ Genomic DNA Purification Kit (\#K0722, Thermo Scientific, Waltham MA, USA), according to the manufacturer's instructions. All extracted DNA samples were genotyped by polymerase chain reaction-restriction fragment length polymorphism (PCR-RFLP) to detect $-1031 \mathrm{~T} / \mathrm{C}$ (rs1799964), -863C/A (rs1800630), $-857 \mathrm{C} / \mathrm{T}$ (rs1799724), and $-308 \mathrm{G} / \mathrm{A}$ (rs1800629) polymorphisms in the promoter of TNF- $\alpha$ gene according to Skoog et al. ${ }^{16}$. Genotyping of the -1031T/C polymorphism was performed by amplifying a DNA fragment with the forward primer $5^{\prime}$-TATGTGATGGACTCACCAGGT- $3^{\prime}$ and the reverse primer $5^{\prime}$-CCTCTACATGGCCCTGTCTT- $3^{\prime}$. The amplified fragment was cut with the restriction enzyme BbsI (\#ER1011, Thermo Scientific, Waltham MA, USA). Genotyping for the $-863 \mathrm{C} / \mathrm{A}$ and $-857 \mathrm{C} / \mathrm{T}$ polymorphisms were performed by amplifying fragments with the common forward primer $5^{\prime}$ GGCTCTGAGGAATGGGTTAC- $3^{\prime}$ and the reverse primer $5^{\prime}$-CTACATGGCCCTGTCTTCGTTACG$3^{\prime}$ for $-863 \mathrm{C} / \mathrm{A}$, and the reverse primer $5^{\prime}$ CCTCTACATGGCCCTGTCTAC- $3^{\prime}$ for $-857 \mathrm{C} / \mathrm{T}$. The two types of amplified fragments were digested with the restriction enzyme TaiI (\#ER1141, Thermo Scientific, Waltham MA, USA). Genotyping of the -308G/A polymorphism was performed by amplifying a DNA fragment with the forward primer $5^{\prime}$ GAGGCAATAGGTTTTGAGGGCCAT- $3^{\prime}$ and the reverse primer $5^{\prime}$-GGGACACACAAGCATCAAG$3^{\prime}$. The amplified fragment was digested with the restriction enzyme NcoI (\#ER0571, Thermo Scientific, Waltham MA, USA).

Each PCR was a $25 \mu \mathrm{L}$ reaction mixture, containing $25 \mathrm{ng}$ of gDNA, ten pmoles of each primer, $12.5 \mu \mathrm{L}$ of Hot Start PCR master mix (\#K1051, Thermo Scientific, Waltham MA, USA). PCRs were conducted using a thermocycler (Multigene, Labnet, Edison NJ, USA) under the following conditions: $95^{\circ} \mathrm{C} \times 10 \mathrm{~min}$, $\left(95^{\circ} \mathrm{C} \times 30 \mathrm{sec}, 60^{\circ} \mathrm{C} \times 30 \mathrm{sec}, 72^{\circ} \mathrm{C} \times 30 \mathrm{sec}\right) \times 35$ cycles, and $72^{\circ} \mathrm{C} \times 5 \mathrm{~min}$.

Digestion reactions were done in $30 \mu \mathrm{L}$ reaction mixtures according to the enzyme manufacturer's instructions at the recommended temperature for $16 \mathrm{hrs}$. Digested products were run side by side with equivalent amounts of undigested PCR products on 5\% agarose gels for $1 \mathrm{hr}$ in TBE buffer, except for $-1031 \mathrm{~T} / \mathrm{C}$ polymorphism where the products were run on $3 \%$ gels. Gels were stained with ethidium eromide and documented in the Photo Doc-IT Imaging System (UVP, Upland CA, USA).

\section{Quantitation of TNF- $\alpha$ mRNA expression}

Total RNA was isolated from all samples by Gene $\mathrm{JET}^{\mathrm{TM}}$ RNA extraction kit (\#K0731, Thermo Scientific, Waltham MA, USA) according to the manufacturer's instructions. cDNA was produced from pure RNA preparations by means of RevertAid ${ }^{\mathrm{TM}}$ First Strand cDNA Synthesis Kit (\#K1631, Thermo Scientific, Waltham MA, USA), according to the recommended instructions. cDNA preparations were used immediately or stored at $-20^{\circ} \mathrm{C}$ when necessary.

Quantitative Real Time PCR for TNF- $\alpha$ was performed by Maxima SYBR Green PCR Master Mix (\#K0251, Thermo Scientific, Waltham MA, USA) in $20 \mu \mathrm{L}$ reaction mixtures, following the recommended instructions. TNF- $\alpha$ expression was quantitated using the forward primer $5^{\prime}$ CTTCTCCTTCCTGATCGTGG- $3^{\prime}$ and the reverse primer $\quad 5^{\prime}$-CCCTGGGGAACTCTTCCCTCT$3^{\prime 17}$. $\quad \beta$-actin was quantitated as a housekeeping gene, using the forward primer $5^{\prime}$ CCTTCTACAAATGAGCTGCGT- $3^{\prime}$ and the reverse primer $5^{\prime}$-CCTGGATAGCAACGTACATG$3^{\prime}$. Reactions were cycled in CFX96 Real Time PCR detection system (Bio-Rad, CA, USA) as follows: $95^{\circ} \mathrm{C} \times 10 \mathrm{~min},\left(95^{\circ} \mathrm{C} \times 15 \mathrm{sec}, 60^{\circ} \mathrm{C} \times 20 \mathrm{sec}, 72^{\circ} \mathrm{C}\right.$ $\times 30 \mathrm{sec}) \times 40$ cycles. Data were analyzed by the $\Delta \mathrm{Ct}$ method. 


\section{DNA sequencing}

DNA isolated from 10 subjects was amplified by PCR as mentioned above using the forward primer $5^{\prime}$-TATGTGATGGACTCACCAGGT- $3^{\prime}$ and the reverse primer $5^{\prime}$-ATCTGGAGGAAGCGGTAGTG-3'. PCR products were purified by The MEGAquickspin Plus Total Fragment DNA Purification Kit (\#MQP17289, Intron, Seol, South Korea) according to the manufacturer's instructions and sequenced by the standard Sanger method at Macrogen sequencing facility (Macrogen, Seol, South Korea). Chromatograms were checked, and the sequences were aligned to the TNF- $\alpha$ gene reference sequence (GenBank: NG_007462).

\section{Statistical analysis}

Results were statistically evaluated using the SPSS package version 22 (IBM Inc., New York, USA). TNF$\alpha$ expression was statistically assessed by Student's ttest, and $\mathrm{P}$ value 0.05 was considered statistically significant. Genotype and allele distributions were tested by the Chi-squared test. The distribution of TNF- $\alpha$ promoter genotypes in each group was checked for deviations from Hardy-Weinberg equilibrium using a web-based tool ${ }^{18}$.

\section{RESULTS}

\section{Genotype frequencies}

To investigate whether there is an association between TNF- $\alpha$ gene polymorphisms and the risk of infection with HCV, DNA was extracted from the blood of $50 \mathrm{HCV}$ RNA positive-patients and 50 healthy subjects, and TNF- $\alpha$ gene promoter was investigated by RFLP technique for the presence of 4 different polymorphisms; $-1031 \mathrm{~T} / \mathrm{C},-863 \mathrm{C} / \mathrm{A},-857 \mathrm{C} / \mathrm{T}$, and $-308 \mathrm{G} / \mathrm{A}$.

For $-1031 \mathrm{~T} / \mathrm{C}$ polymorphism, the homozygous wild TT genotype was detected in $50 \%$ of the HCV patients and $60 \%$ of the healthy subjects, while the heterozygous TC genotype was detected in $44 \%$ of HCV patients and $34 \%$ of healthy subjects. The homozygous CC genotype was detected in $6 \%$ of HCV patients and, also, $60 \%$ of healthy subjects (Figure $1 \mathrm{~A} \& \mathrm{~B}$ ).

For $-863 \mathrm{C} / \mathrm{A}$ polymorphism, the homozygous wild CC genotype was detected in $68 \%$ of HCV patients and $66 \%$ of the healthy subjects, while the heterozygous genotype was detected in $32 \%$ of HCV patients and $34 \%$ of the healthy subjects. The homozygous AA genotype was not detected in either HCV patients or the healthy subjects (Figure 1C\&D).

With respect to $-857 \mathrm{C} / \mathrm{T}$ polymorphism, the homozygous wild CC genotype was detected in $74 \%$ of
HCV patients and $76 \%$ of the healthy subjects, while the heterozygous genotype was detected in $24 \%$ of both HCV patients and the healthy subjects. The homozygous TT genotype was detected in $2 \%$ of $\mathrm{HCV}$ patients and was not detected in any of the healthy subjects (Figure 1E\&F).

Regarding -308G/A polymorphism, the homozygous wild GG genotype was detected in $88 \%$ of HCV patients and $84 \%$ of the healthy subjects, while the heterozygous GA genotype was detected in $12 \%$ of $\mathrm{HCV}$ patients and $16 \%$ of the healthy subjects. The homozygous AA genotype was not detected in both the HCV patients and healthy subjects (Figure 1G\&H).

There were no significant differences in the observed frequency of any genotype between $\mathrm{HCV}$ patients and the healthy subjects (Table 1 ). The distributions of all genotypes among these two groups were both in Hardy-Weinberg equilibrium (Table 2).

\section{Frequencies of allele carriage}

Rates of allele carriage in HCV patients or healthy subjects were calculated (Table 2). The $-1031 \mathrm{~T}$ allele was carried by $94 \%$ of either HCV patients or healthy subjects, and the $-1031 \mathrm{C}$ allele was carried by $50 \%$ of HCV patients and $40 \%$ of healthy subjects, respectively. The $-863 \mathrm{C}$ allele was carried by $100 \%$ of either HCV patients or healthy subjects, and the $-863 \mathrm{~A}$ allele was carried by $32 \%$ of $\mathrm{HCV}$ patients and $34 \%$ of healthy subjects. The $-857 \mathrm{C}$ allele was carried by $98 \%$ of HCV patients and $100 \%$ of the healthy subjects; the $-857 \mathrm{~T}$ allele was carried by $26 \%$ of $\mathrm{HCV}$ patients and $24 \%$ of the healthy subjects. The $-308 \mathrm{G}$ allele was carried by $100 \%$ of both $\mathrm{HCV}$ patients and the healthy subjects, and the $-308 \mathrm{~A}$ allele was carried by $12 \%$ of HCV patients and $16 \%$ of the healthy subjects. The differences in these allele frequencies were statistically insignificant (Table 3).

Frequencies of allele carriage in the studied Egyptian population (HCV patients plus healthy subjects) were summarized in Table 4. The wild-type $-1031 \mathrm{~T}$, $-863 \mathrm{C},-857 \mathrm{C}$, and $-308 \mathrm{G}$ alleles were highly distributed $(p=0.00)$ in the Egyptian population than the non-wild alleles.

\section{Partial sequencing of TNF- $\alpha$ gene promoter}

To confirm the PCR-RFLP genotyping results and compare the sequence of the TNF- $\alpha$ gene promoter in Egyptians with the reference TNF- $\alpha$ gene sequence (GenBank: NG_007462), the promoter region (-1063 to -230 ), spanning the four studied polymorphisms were sequenced. Sequence results confirmed the 
Table 1: Distribution of different genotypes in HCV patients and apparently healthy subjects

\begin{tabular}{|c|c|c|c|c|c|c|c|}
\hline \multirow[t]{2}{*}{ Polymorphism } & \multirow[t]{2}{*}{ Genotype } & \multicolumn{2}{|c|}{$\mathrm{HCV}$ patients } & \multicolumn{2}{|c|}{ Healthy subjects } & \multirow[t]{2}{*}{$\chi^{2}$} & \multirow[t]{2}{*}{ p-value } \\
\hline & & $\mathrm{N}=\mathbf{5 0}$ & $\%$ & $\mathrm{~N}=\mathbf{5 0}$ & $\%$ & & \\
\hline \multirow{3}{*}{$-1031 \mathrm{~T} / \mathrm{C}$} & $\mathrm{TT}$ & 25 & 50 & 30 & 60 & 1.01 & 0.42 \\
\hline & $\mathrm{TC}$ & 22 & 44 & 17 & 34 & 1.05 & 0.41 \\
\hline & $\mathrm{CC}$ & 3 & 6 & 3 & 6 & 0.00 & 1.00 \\
\hline \multirow{3}{*}{$-863 \mathrm{C} / \mathrm{A}$} & $\mathrm{CC}$ & 34 & 68 & 33 & 66 & 0.45 & 1.00 \\
\hline & $\mathrm{CA}$ & 16 & 32 & 17 & 34 & 0.45 & 1.00 \\
\hline & AA & 0 & 0 & 0 & 0 & - & - \\
\hline \multirow{3}{*}{$-857 \mathrm{C} / \mathrm{T}$} & $\mathrm{CC}$ & 37 & 74 & 38 & 76 & 0.05 & 1.00 \\
\hline & $\mathrm{CT}$ & 12 & 24 & 12 & 24 & 0.00 & 1.00 \\
\hline & $\mathrm{TT}$ & 1 & 2 & 0 & 0 & 1.01 & 1.00 \\
\hline \multirow{3}{*}{$-308 \mathrm{G} / \mathrm{A}$} & GG & 44 & 88 & 42 & 84 & 0.33 & 0.77 \\
\hline & GA & 6 & 12 & 8 & 16 & 0.33 & 0.77 \\
\hline & $\mathrm{AA}$ & 0 & 0 & 0 & 0 & - & - \\
\hline
\end{tabular}

Table 2: Chi-squared test for the deviation of genotypes from Hardy-Weinberg equilibrium

\begin{tabular}{llllll}
\hline Locus & Genotype & \multicolumn{2}{c}{ HCV patients } & \multicolumn{2}{c}{ Healthy subjects } \\
& & Frequency & HWE $\chi^{2}$ & Frequency & HWE $\chi^{2}$ \\
-1031 & TT, TC, CC & $25,22,3$ & 0.42 & $3,17,30$ & 0.08 \\
-863 & CC, CA, AA & $34,16,0$ & 1.81 & $0,17,33$ & 2.10 \\
-857 & CC, CT, TT & $37,12,1$ & 0.00 & $38,12,0$ & 0.93 \\
-308 & GG, GA, AA & $44,6,0$ & 0.20 & $42,8,0$ & 0.38 \\
\hline
\end{tabular}

${ }^{*}$ If the calculated $\chi^{2}$ value is 3.84 , it is considered significant $(p=0.05)$

Table 3: Frequencies of different alleles in HCV patients and apparently healthy subjects

\begin{tabular}{lcccccc}
\hline Allele & \multicolumn{2}{c}{ HCV patients } & \multicolumn{2}{c}{ Healthy subjects } & $\chi^{2}$ & p-value \\
& $\mathbf{N}=\mathbf{5 0}$ & $\mathbf{\%}$ & $\mathbf{N}=\mathbf{5 0}$ & $\mathbf{\%}$ & & \\
$-1031 \mathrm{~T}$ & 47 & 94 & 47 & 94 & 0.00 & 1.00 \\
$-1031 \mathrm{C}$ & 25 & 50 & 20 & 40 & 0.72 & 0.50 \\
$-863 \mathrm{C}$ & 50 & 100 & 50 & 100 & 0.00 & 1.00 \\
$-863 \mathrm{~A}$ & 16 & 32 & 17 & 34 & 0.03 & 1.00 \\
$-857 \mathrm{C}$ & 49 & 98 & 50 & 100 & 0.02 & 1.00 \\
$-857 \mathrm{~T}$ & 13 & 26 & 12 & 24 & 0.04 & 1.00 \\
$-308 \mathrm{G}$ & 50 & 100 & 50 & 100 & 0.00 & 1.00 \\
$-308 \mathrm{~A}$ & 6 & 12 & 8 & 16 & 0.30 & 0.78 \\
\hline
\end{tabular}



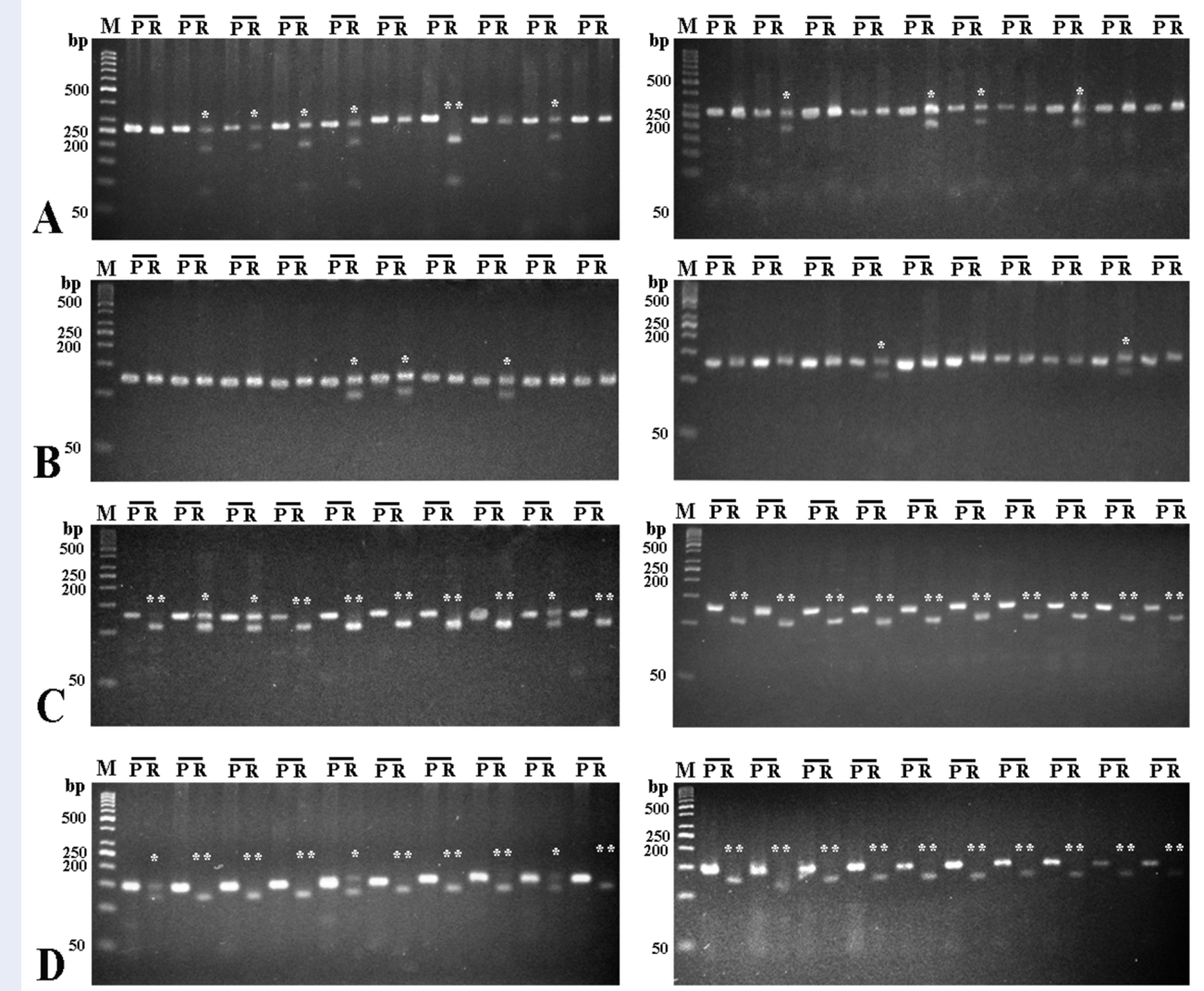

Figure 1: Representative results of PCR-RFLP performed on TNF- $\alpha$ gene in HCV patients and apparently healthy subjects. 10 representative restriction digestion reactions on HCV patients (Left panels) and 10 representative reactions on healthy subjects (Right panels) are shown. Rows $A, B, C$ and $D$ show restriction patterns obtained with $\mathrm{Bbsl}$ digestion (-1031 T/C polymorphism), with Tail digestion (-863 C/A polymorphism), with Tail digestion $(-857 \mathrm{C} / \mathrm{T}$ polymorphism) and with Ncol digestion ( $-308 \mathrm{G} / \mathrm{A}$ polymorphism), respectively. " $\mathrm{M}$ " denotes 50 bp DNA ladder. "P" denotes lanes containing undigested PCR products while " $R$ " denotes lanes containing digested PCR products. "**" denotes heterozygous genotypes and "**" denotes homozygous genotypes.

Table 4: Frequencies ofdifferent alleles in the studied Egyptian population

\begin{tabular}{lccc}
\hline Allele & Population $(\mathbf{N}=\mathbf{1 0 0}) \%$ & $\chi^{2}$ & p-value \\
\hline$-1031 \mathrm{~T}$ & 94 & 26.47 & 0.00 \\
$-1031 \mathrm{C}$ & 45 & 50.00 & 0.00 \\
\hline$-863 \mathrm{C}$ & 100 & & 0.00 \\
$-863 \mathrm{~A}$ & 33 & 64.00 & \\
\hline$-857 \mathrm{C}$ & 99 & & 0.00 \\
$-857 \mathrm{~T}$ & 25 & 90.73 & \\
\hline$-308 \mathrm{G}$ & 100 & & \\
\hline$-308 \mathrm{~A}$ & 14 & & \\
\hline
\end{tabular}


polymorphic patterns drawn from the PCR-RFLP results. Additionally, the nucleotide variance in this promoter region of 10 studied subjects ( 5 healthy subjects and $5 \mathrm{HCV}$ patients) was identical to the reference sequence, except for the known polymorphisms $-1031 \mathrm{~T} / \mathrm{C},-863 \mathrm{C} / \mathrm{A},-857 \mathrm{C} / \mathrm{A},-376 \mathrm{G} / \mathrm{A}$, $-308 \mathrm{G} / \mathrm{A}$, and $-238 \mathrm{G} / \mathrm{A}$ (Table 5).

\section{Quantitation of TNF- $\alpha$ mRNA expression}

Expression of TNF- $\alpha$ mRNA in HCV patients and the healthy subjects was evaluated by real-time PCR. The relative TNF- $\alpha$ mRNA expression in HCV patients and the healthy subjects was statistically indifferent $(\mathrm{p}=0.21)$ (Figure 2).

\section{DISCUSSION}

TNF- $\alpha$ has been considered the fundamental pathogenic mediator in various liver conditions, including hepatic fibrogenesis and fibrosis progression in chronic liver disease ${ }^{19}$. It has been shown that TNF- $\alpha$ aids in activating hepatic stellate cells and transforming them into an activated myofibroblastlike phenotype, which leads to accumulation of extracellular matrix and fibrosis development ${ }^{20}$. Besides, TNF- $\alpha$ is thought to prompt the production of other fibrogenic factors, such as tumor growth factor- $\beta$, IL- 1 , and IL- $6^{21}$.

TNF- $\alpha$ levels increase in patients with HBV infection $^{22}$, and TNF- $\alpha$ production has been linked to the polymorphisms in its promoter region ${ }^{23}$. Some polymorphisms in TNF- $\alpha$ promoter were correlated with the severity of liver disease in HBV patients and thought to influence the susceptibility to chronicity, which outcomes as cirrhosis, or $\mathrm{HCC}^{24}$.

This study investigated the polymorphisms in 4 consecutive loci in the TNF- $\alpha$ promoter; $-1031 \mathrm{~T} / \mathrm{C}$, $-863 \mathrm{C} / \mathrm{A},-857 \mathrm{C} / \mathrm{T}$, and $-308 \mathrm{G} / \mathrm{A}$, in a population of $\mathrm{HCV}$ infected Egyptian patients. Compared to the healthy subjects, the observed frequency of all genotypes and alleles in HCV patients and the healthy subjects were statistically indifferent. The distributions of all genotypes among HCV patients and the healthy subjects were both in the Hardy-Weinberg equilibrium. None of the four studied polymorphisms were associated with $\mathrm{HCV}$ infection. Additionally, the wild-type $-1031 \mathrm{~T},-863 \mathrm{~A},-857 \mathrm{C}$, and $-308 \mathrm{G}$ alleles were highly common among the studied Egyptian population. The sequence of the promoter region, spanning the four studied polymorphisms did not reveal any nucleotide difference from the GenBank TNF- $\alpha$ reference sequence, except for the known polymorphisms.
Studies correlating susceptibility to $\mathrm{HCV}$ infection with certain TNF- $\alpha$ promoter polymorphisms are limited and conflicting. A significant association between TNF- $\alpha-308$ GG genotype and HCV infections in Indian patients compared with healthy individuals was reported ${ }^{9}$. Talaat et al. ${ }^{25}$ reported a significantly higher TNF- $\alpha-308 \mathrm{G}$ allele frequency in HCVinfected Egyptian patients, compared with healthy controls, and a higher frequency of TNF- $\alpha-308 \mathrm{~A}$ allele in healthy control individuals. In contrast to this, TNF- $\alpha-308$ A allele was significantly associated with HCV infection among Egyptian patients ${ }^{26}$. Except for $-308 \mathrm{G} / \mathrm{A}$, no other TNF- $\alpha$ polymorphisms were investigated in Egyptian HCV patients.

Several studies correlated TNF- $\alpha$ polymorphisms with the chronicity of $\mathrm{HCV}$ infection, the susceptibility to HCC development and response to therapy. TNF- $\alpha-308 \mathrm{G} / \mathrm{A}$ polymorphism was involved in the pathogenesis and advancement of $\mathrm{CHC}$ in Caucasian patients ${ }^{7,8}$. Both TNF- $\alpha-308 \mathrm{G} / \mathrm{A}$ and $-857 \mathrm{C} / \mathrm{T}$ polymorphisms were significantly associated with acute viral hepatitis in Indians ${ }^{27}$. These results are inconsistent with several studies which did not notice any association between TNF- $\alpha-308 \mathrm{G} / \mathrm{A}$ polymorphisms and severity of fibrosis in CHC Caucasian Spanish patients ${ }^{28}$, Tunisian patients ${ }^{29}$, and Indian patients ${ }^{9}$. The severity of $\mathrm{CHC}$ infection was not associated with TNF- $\alpha-308 \mathrm{G} / \mathrm{A}$ polymorphisms in Caucasian patients and Irish patients ${ }^{30,31}$. TNF- $\alpha-308 \mathrm{~A}$ allele was associated with increased susceptibility to severe HCV recurrence after transplant $^{7}$ and with a 3.2-fold increased risk of cirrhosis for Caucasian patients, having chronic HCV infection ${ }^{8}$. However, no association was recorded between TNF- $\alpha-308 \mathrm{G} / \mathrm{A}$ polymorphisms and susceptibility to chronic HCV infection, or viral persistence in Taiwanese patients ${ }^{32}$. Similarly, meta-analysis studies ${ }^{33,34}$ stated the absence of such an association. Besides, no association between -308G/A polymorphisms and liver cirrhosis risk was noticed in both Caucasian and Asian patients ${ }^{35}$. In HCV-infected Pakistani patients, sustained virological response was not affected by TNF- $\alpha-308 \mathrm{G} / \mathrm{A}$ polymorphism ${ }^{36}$.

Generally, data of the studies on TNF- $\alpha$ genetic polymorphisms have been reported to vary from one study to another, and such variation was related to the differences in the ethnic origins or the number of the individuals involved in the study ${ }^{6}$. Additionally, the difference in applied techniques, as well as the data interpretation, could contribute to the aforementioned discrepancy.

A lack of association between the four studied polymorphisms and HCV infection in the current study 
Table 5: Nucleotide variance in the region -1063 to -230 of TNF- $\alpha$ promoter in $5 \mathrm{HCV}$ patients and 5 healthy subjects

\begin{tabular}{|c|c|c|c|c|c|c|c|c|c|c|c|c|}
\hline $\begin{array}{l}\text { Reference } \\
\text { sequence }\end{array}$ & & $\begin{array}{l}\text { Healtl } \\
\# 1\end{array}$ & $\begin{array}{c}\text { Healtr } \\
\# 2\end{array}$ & $\begin{array}{l}\text { Healt } \\
\# 3\end{array}$ & $\begin{array}{c}\text { Health } \\
\# 4\end{array}$ & $\begin{array}{c}\text { Healthy } \\
\# 5\end{array}$ & $\begin{array}{c}\text { HCV } \\
\# 1\end{array}$ & $\begin{array}{c}\mathrm{HCV} \\
\# 2\end{array}$ & $\begin{array}{c}\text { HCV } \\
\# 3\end{array}$ & $\begin{array}{c}\mathrm{HCV} \\
\# 4\end{array}$ & $\begin{array}{c}\text { HCV } \\
\# 5\end{array}$ & Total \\
\hline$-1,031$ & $\mathrm{~T}$ & & & C & C & C & & C & $\mathrm{C}$ & $\mathrm{C}$ & & 6 \\
\hline-863 & $\mathrm{C}$ & & & & M & A & & & A & & & 3 \\
\hline-857 & $\mathrm{C}$ & & & & & & & $\mathrm{T}$ & & & & 1 \\
\hline-376 & G & & & A & A & & & $\mathrm{R}$ & & & & 3 \\
\hline-308 & G & $\mathrm{R}$ & $\mathrm{R}$ & & & A & A & & & & & 4 \\
\hline-238 & G & $\mathrm{R}$ & & A & A & $\mathrm{R}$ & A & $\mathrm{R}$ & & A & & 7 \\
\hline $\begin{array}{l}\text { Total } \\
\text { differences }\end{array}$ & & 2 & 1 & 3 & 4 & 4 & 2 & 4 & 2 & 2 & & 24 \\
\hline
\end{tabular}

$\mathrm{R}(\mathrm{A} / \mathrm{G}), \mathrm{M}(\mathrm{A} / \mathrm{C})$

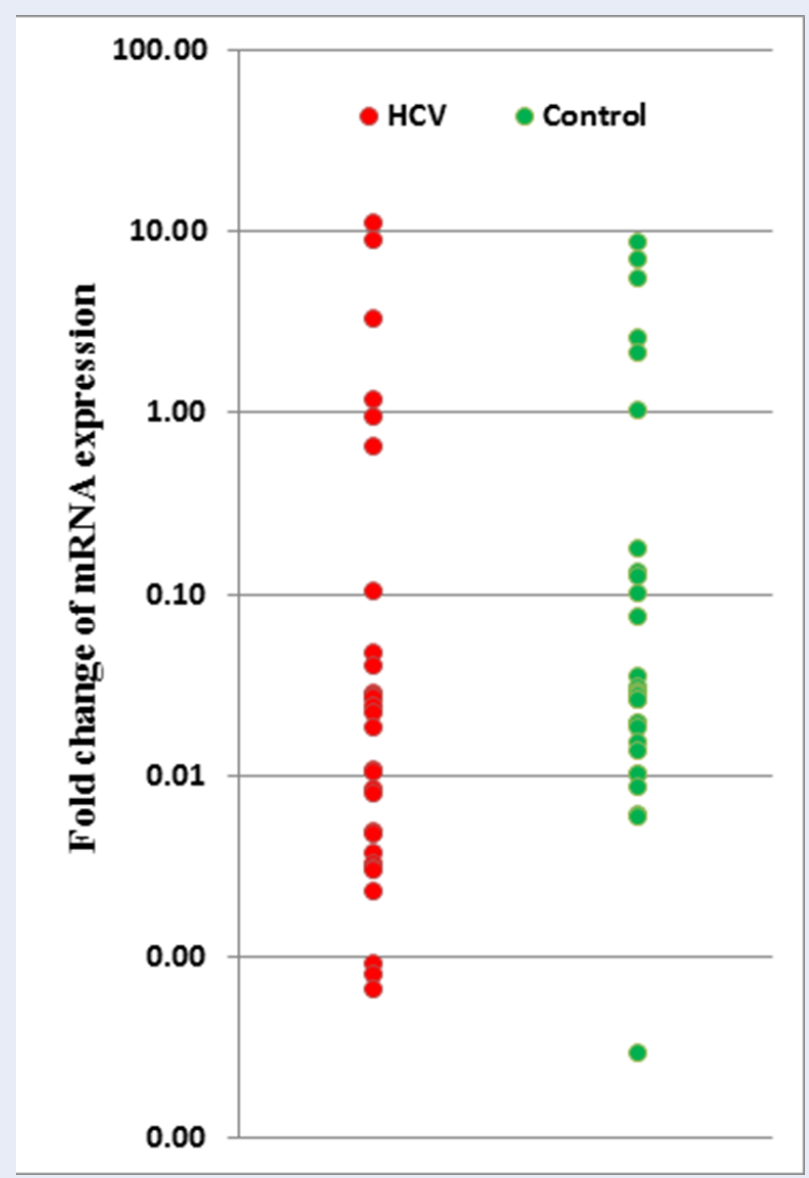

Figure 2: Relative expression of TNF- $\alpha$ in HCV patients and apparently healthy subjects. The mRNA expression of TNF-a was calculated relativeto $\beta$-actin expression in HCV patients and healthy subjects using the $\triangle \mathrm{Ct}$ method. 
has prompted determining TNF- $\alpha$ expression in HCV patients. Results did not show any significant difference in the relative TNF- $\alpha$ mRNA expression between HCV patients and the healthy subjects, thus supporting the lack of association between the studied genotypes/alleles and HCV infection.

It is documented that genetic polymorphisms, certain promoter sequences, and allelic variants are associated with low or high cytokine production in vitro and in vivo ${ }^{23,37}$. Polymorphisms at the positions -1031 , $-863,-857,-308$, and -238 of TNF- $\alpha$ gene promoter were differentially associated with TNF- $\alpha$ production in different populations ${ }^{38}$.

Individuals with the genotypes -308AA or AG were reported to have higher levels of serum TNF- $\alpha$ and, in contrast to this, individuals with the genotypes $-863 \mathrm{AA}$ or CA were noted to have lower TNF- $\alpha$ level ${ }^{39}$. Although the allele $-308 \mathrm{~A}$ is commonly associated with increased production of TNF- $\alpha^{23,40}$, some other studies ${ }^{41,42}$ demonstrated that $-308 \mathrm{G} / \mathrm{A}$ polymorphism does not have a significant effect on TNF expression. In Chinese populations, the genotypes -308GA and AA were correlated with decreased serum TNF- $\alpha$ level $^{43}$.

TNF- $\alpha-863 \mathrm{C} / \mathrm{A}$ polymorphism was reported to impact binding of nuclear proteins to the promoter region of the TNF- $\alpha$ gene, causing variation in the serum TNF- $\alpha$ level. Specifically, the $-863 \mathrm{~A}$ allele had significantly less serum TNF- $\alpha$ quantity ${ }^{16}$. In the current study, the genotypes -308AA or AG were less frequent in both $\mathrm{HCV}$ patients and healthy subjects; however, the $-863 \mathrm{~A}$ allele showed a $100 \%$ occurrence frequency in both groups.

Previous studies indicated that both of the $-857 \mathrm{~T}$ and $-857 \mathrm{C}$ alleles caused high levels of transcriptional activity of TNF- $\alpha$ mRNA and protein with a stronger effect for $-857 \mathrm{~T}$ allele ${ }^{44}$. The $-857 \mathrm{~T}$ allele caused a 1.7fold higher level of transcription activity, compared to the $-857 \mathrm{C}$ allele ${ }^{45}$. In the current study, the allele $-857 \mathrm{~T}$ was highly frequent in both HCV patients and healthy subjects.

Studies on the effect of $-1031 \mathrm{~T} / \mathrm{C}$ polymorphism on TNF- $\alpha$ expression are very limited. In Chinese populations, the genotype -1031TC and CC was correlated with decreased serum TNF- $\alpha$ level. Chinese $-308 \mathrm{G} / \mathrm{A},-857 \mathrm{C} / \mathrm{T}$, and $-1031 \mathrm{~T} / \mathrm{C}$ combination carriers had lower serum TNF- $\alpha$ level than the carriers of the corresponding wild type ${ }^{43}$.

TNF- $\alpha$ promoter polymorphisms do affect TNF- $\alpha$ expression level, but the activation and abundance of other molecules that directly or indirectly interact with certain promoter sequences must affect the expression of TNF- $\alpha^{6}$.
Identification of the genetic factors associated with HCV susceptibility and severity is fundamental for understanding the mechanism, provoking the development of chronic hepatitis into cirrhosis and HCC. Such Identification also facilitates implementing suitable treatment strategies. Due to the absence of absolute quantitation of TNF- $\alpha$ level in this study, it is uncertain whether TNF- $\alpha$ level was high or low in both HCV patients and the healthy subjects of the studied Egyptian population. Although, most of the previous studies that discussed the role of TNF- $\alpha$ support the notion of an increase in TNF- $\alpha$ level in case of viral infections. The similarity in TNF- $\alpha$ mRNA expression in both HCV patients and the healthy subjects in the Egyptian population rises several essential questions. Firstly, whether the mechanisms of the posttranscriptional and posttranslational modifications of the TNF- $\alpha$ gene in HCV patients, compared to the healthy subjects are the same? Secondly, whether the ethnic nature predisposes the Egyptian population to some TNF- $\alpha$-related diseases like viral infections, autoimmune diseases, and cancers if this cytokine is left uncontrolled? Additional studies on TNF- $\alpha$ expression in a large population of Egyptians may provide certain answers.

\section{CONCLUSION}

This study investigated the distribution of 4 TNF- $\alpha$ gene promoter polymorphisms (-1031T/C, $-863 \mathrm{C} / \mathrm{A}$, $-857 \mathrm{C} / \mathrm{T}$, and $-308 \mathrm{G} / \mathrm{A}$ ) and their relation to TNF- $\alpha$ expression in $\mathrm{HCV}$-infected Egyptian patients. None of these polymorphisms were associated with $\mathrm{HCV}$ infection. The promoter region spanning these polymorphisms in some subjects was similar to the TNF- $\alpha$ GenBank reference sequence. No significant difference was detected in the relative TNF- $\alpha$ mRNA expression between HCV patients and healthy subjects. Further studies are needed to determine whether the post-transcriptional and posttranslational modifications of TNF- $\alpha$ in HCV patients and healthy subjects are different.

\section{ABBREVIATIONS}

CHC: chronic hepatitis C

HBV: hepatitis B virus

HCC: hepatocellular carcinoma

HCV: hepatitis $C$ virus

PCR-RFLP: polymerase chain reaction-restriction fragment length polymorphism

TNF- $\alpha$ : Tumor necrosis factor- $\alpha$

\section{COMPETING INTERESTS}

The author declares that there is no conflict of interest in this study. 


\section{ACKNOWLEDGEMENTS}

The author thanks Radwa R. El-Tahan, Zoology Department, Faculty of Science, Damietta University and Hosam Zaghloul, Department of Clinical Pathology, Faculty of Medicine, Mansoura University, for their help during sample collection. This study was supported by the faculty of Science through facilitating the use of Physiology and Biotechnology laboratory in Zoology department.

\section{REFERENCES}

1. Chen SL, Morgan TR. The natural history of hepatitis $C$ virus (HCV) infection. Int J Med Sci. 2006;3(2):47-52. 16614742. Available from: 10.7150/ijms.3.47.

2. Organization WH. Hepatitis C, fact sheet N 164; 2017. Available from: http://www.who.int/mediacentre/factsheets/fs164/ en/.

3. Coussens LM, Werb Z. Inflammation and cancer. Nature. 2002;420(6917):860-7. 12490959. Available from: 10.1038/ nature 01322.

4. Bradham CA, Plümpe J, Manns MP, Brenner DA, Trautwein C. Mechanisms of hepatic toxicity. I. TNF-induced liver injury. Am J Physiol. 1998;275(3):387-92. 9724248.

5. Locksley RM, Killeen N, Lenardo MJ. The TNF and TNF receptor superfamilies: integrating mammalian biology. Cell. 2001;104(4):487-501. 11239407. Available from: 10.1016/ S0092-8674(01)00237-9.

6. El-Tahan RR, Ghoneim AM, El-Mashad N. TNF- $\alpha$ gene polymorphisms and expression. Springerplus. 2016;5(1):1508. 27652081. Available from: 10.1186/s40064-016-3197-y.

7. Rosen HR, Lentz JJ, Rose SL, Rabkin J, Corless CL, Taylor $\mathrm{K}$ et al. Donor polymorphism of tumor necrosis factor gene: relationship with variable severity of hepatitis $C$ recurrence after liver transplantation. Transplantation. 1999;68(12):1898-902. 10628771. Available from: 10.1097/00007890-19991227000014.

8. Yee LJ, Tang J, Herrera J, Kaslow RA, van Leeuwen DJ. Tumor necrosis factor gene polymorphisms in patients with cirrhosis from chronic hepatitis $C$ virus infection. Genes Immun. 2000;1(6):386-90. 11196686. Available from: 10.1038/sj.gene. 6363696.

9. Dogra G, Chakravarti A, Kar P, Chawla YK. Polymorphism of tumor necrosis factor- $\alpha$ and interleukin-10 gene promoter region in chronic hepatitis $C$ virus patients and their effect on pegylated interferon- $\alpha$ therapy response. Hum Immunol. 2011;72(10):935-9. 21756957. Available from: 10.1016/j. humimm.2011.06.008.

10. Dai CY, Chuang WL, Chang WY, Chen SC, Lee LP, Hsieh MY, et al. Tumor necrosis factor alpha promoter polymorphism at position - 308 predicts hepatitis $C$ virus response to combination therapy. J Infect Dis. 2006;193(1):98-101. 16323137. Available from: 10.1086/498244

11. Yang Y, Luo C, Feng R, Bi S. The TNF- $\alpha$, IL-1B and IL-10 polymorphisms and risk for hepatocellular carcinoma: a meta-analysis. J Cancer Res Clin Oncol. 2011;137(6):947-52. 21107607. Available from: 10.1007/s00432-010-0959-8.

12. Morsi Ml, Hussein AE, Mostafa M, El-Abd E, El-Moneim NA. Evaluation of tumour necrosis factor-alpha, soluble P-selectin, gamma-glutamyl transferase, glutathione S-transferase-pi and alpha-fetoprotein in patients with hepatocellular carcinoma before and during chemotherapy. $\mathrm{Br} J$ Biomed Sci. 2006;63(2):74-8. 16871999. Available from: 10.1080/ 09674845.2006 .11732724

13. Xiao Q, Fu B, Chen P, Liu ZZ, Wang W, Ye Q. Three polymorphisms of tumor necrosis factor-alpha and hepatitis $B$ virus related hepatocellular carcinoma: A meta-analysis. Medicine (Baltimore). 2016;95(50):e5609. 27977601. Available from: 10.1097/MD.0000000000005609.
14. Li Y, Ou C, Shu H, Zhao H, Zhu B. The ERCC1-4533/8092, TNF- $\alpha$ $238 / 308$ polymorphisms and the risk of hepatocellular carcinoma in Guangxi Zhuang populations of China: case-control study. Medicine (Baltimore). 2016;95(44):e5217. 27858866. Available from: 10.1097/MD.0000000000005217.

15. Mohamoud YA, Mumtaz GR, Riome S, Miller D, Abu-Raddad LJ. The epidemiology of hepatitis $C$ virus in Egypt: a systematic review and data synthesis. BMC Infect Dis. 2013;13(1):288. 23799878. Available from: 10.1186/1471-2334-13-288.

16. Skoog T, van't Hooft FM, Kallin B, Jovinge $S$, Boquist $S$, Nilsson $\mathrm{J}$, et al. A common functional polymorphism ( $C \longrightarrow$ A substitution at position -863) in the promoter region of the tumour necrosis factor-alpha (TNF-alpha) gene associated with reduced circulating levels of TNF-alpha. Hum Mol Genet. 1999;8(8):1443-9. 10400991. Available from: 10.1093/hmg/ 8.8.1443.

17. Mousa AK, Ghoneim AM, El-Mashad NB, El-Ghobashy A. TNF\% UNKNOWN UNICODE CHARACTER 02011 (NON-BREAKING HYPHEN) $\alpha$ genetic polymorphisms and its expression in Egyptian rheumatoid arthritis patients. Am J Life Sci. 2014;2(4):234-40. Available from: 10.11648/j.ajls.20140204.17.

18. Rodriguez S, Gaunt TR, Day IN. Hardy-Weinberg equilibrium testing of biological ascertainment for Mendelian randomization studies. Am J Epidemiol. 2009;169(4):505-14. 19126586. Available from: 10.1093/aje/kwn359.

19. Richardson MM, Powell EE, Barrie HD, Clouston AD, Purdie $\mathrm{DM}$, Jonsson JR. A combination of genetic polymorphisms increases the risk of progressive disease in chronic hepatitis $C$. J Med Genet. 2005;42(7):e45-45. 15994870. Available from: 10.1136/jmg.2005.032557.

20. Özdemir BH, Bilezikçi B, Haberal M. Hepatic stellate cells in hepatitis $C$ patients: relationship with the development of interstitial fibrosis in renal allografts. Transplant Proc. 2009;41(7):2838-40. 19765451. Available from: 10.1016/j. transproceed.2009.07.032.

21. Balkwill F. Cancer and the chemokine network. Nat Rev Cancer. 2004;4(7):540-50. 15229479. Available from: 10.1038/ nrc1388.

22. Zhang G, Li Z, Han Q, Li N, Zhu Q, Li F, et al. Altered TNF$\alpha$ and IFN- $\gamma$ levels associated with PD1 but not TNFA polymorphisms in patients with chronic HBV infection. Infect Genet Evol. 2011;11(7):1624-30. 21712100. Available from: 10.1016/j.meegid.2011.06.004.

23. Wilson AG, Symons JA, McDowell TL, McDevitt HO, Duff GW. Effects of a polymorphism in the human tumor necrosis factor alpha promoter on transcriptional activation. Proc Natl Acad SciUSA. 1997;94(7):3195-9. 9096369. Available from: 10.1073/ pnas.94.7.3195.

24. Du T, Guo XH, Zhu XL, Li JH, Lu LP, Gao JR, et al. Association of TNF-alpha promoter polymorphisms with the outcomes of hepatitis B virus infection in Chinese Han population. J Viral Hepat. 2006;13(9):618-24. 16907849. Available from: 10.1111/ j.1365-2893.2006.00731.x.

25. Talaat RM, Esmail AA, Elwakil R, Gurgis AA, Nasr MI. Tumor necrosis factor-alpha -308G/A polymorphism and risk of hepatocellular carcinoma in hepatitis $C$ virus-infected patients. Chin J Cancer. 2012;31(1):29-35. 22200181.

26. Pasha HF, Radwan MI, Hagrass HA, Tantawy EA, Emara MH. Cytokines genes polymorphisms in chronic hepatitis $\mathrm{C}$ : impact on susceptibility to infection and response to therapy. Cytokine. 2013;61(2):478-84. 23219017. Available from: 10 1016/j.cyto.2012.11.003.

27. Singhal S, Kohaar I, Bharadwaj M, Shukla DK, Das BC, Kar P. Association of tumor necrosis factor-alpha gene promoter polymorphisms with acute viral hepatitis in the Indian population. Dig Dis Sci. 2010;55(4):1106-12. 19390969. Available from: 10.1007/s10620-009-0799-z.

28. Romero-Gómez M, Montes-Cano MA, Otero-Fernández MA, Torres B, Sánchez-Muñoz D, Aguilar F, et al. SLC11A1 promoter gene polymorphisms and fibrosis progression in chronic hepatitis C. Gut. 2004;53(3):446-50. 14960532. Available from: 
10.1136/gut.2003.028274.

29. Bouzgarrou N, Hassen E, Gabbouj S, Schvoerer E, Mami NB, Triki $\mathrm{H}$, et al. Lack of effect of tumor necrosis factor-alpha -308 $\mathrm{G} /$ A polymorphism on severity of liver fibrosis in Tunisian hepatitis C virus (HCV)-infected patients. Gastroenterol Clin Biol. 2010;34(4-5):297-304. 20537485. Available from: 10.1016/j. gcb.2010.03.008.

30. Höhler T, Kruger A, Gerken G, Schneider PM, zum Büschenfelde KHM, Rittner C. Tumor necrosis factor alpha promoter polymorphism at position -238 is associated with chronic active hepatitis C infection. J Med Virol. 1998;54(3):173-7. 9515764. Available from: 10.1002/(SICI)1096-9071(199803) 54:3<173::AID-JMV5>3.0.CO;2-2

31. Barrett S, Collins M, Kenny C, Ryan E, Keane CO, Crowe J. Polymorphisms in tumour necrosis factor-alpha, transforming growth factor-beta, interleukin-10, interleukin-6, interferongamma, and outcome of hepatitis C virus infection. J Med Virol. 2003;71(2):212-8. 12938195. Available from: 10.1002/ jmv.10472.

32. Dai CY, Chuang WL, Lee LP, Chen SC, Hou NJ, Lin ZY, et al. Associations of tumour necrosis factor alpha promoter polymorphisms at position -308 and -238 with clinical characteristics of chronic hepatitis C. J Viral Hepat. 2006;13(11):770-4. 17052277. Available from: 10.1111/j.1365-2893.2006.00767.x.

33. Chen Y, Pei J. An assessment of a TNF polymorphic marker for the risk of HCV infection: meta-analysis and a new clinical study design. Infect Genet Evol. 2009;9(6):1356-63. 19800032. Available from: 10.1016/j.meegid.2009.09.010.

34. He J, Pei X, Xu W, Wang C, Zhang X, Wu J, et al. The relationship between tumor necrosis factor- $\alpha$ polymorphisms and hepatitis $C$ virus infection: a systematic review and metaanalysis. Ren Fail. 2011;33(9):915-22. 21851198. Available from: 10.3109/0886022X.2011.605537.

35. Chen D, Liu JL, Liu Y, Zhu J, Wang SW. Lack of an association between $-308 \mathrm{G}>\mathrm{A}$ polymorphism of the TNF- $\alpha$ gene and liver cirrhosis risk based on a meta-analysis. Genet Mol Res. 2011;10(4):2765-74. 22095602. Available from: 10.4238/2011. November.8.2.

36. Abbas Z, Moatter T, Hussainy A, Jafri W. Effect of cytokine gene polymorphism on histological activity index, viral load and response to treatment in patients with chronic hepatitis C genotype 3. World J Gastroenterol. 2005;11(42):6656-61. 16425360. Available from: 10.3748/wjg.v11.i42.6656.

37. Gibson AW, Edberg JC, Wu J, Westendorp RG, Huizinga TW,
Kimberly RP. Novel single nucleotide polymorphisms in the distal IL-10 promoter affect IL-10 production and enhance the risk of systemic lupus erythematosus. J Immunol. 2001;166(6):3915-22. 11238636. Available from: 10.4049/ jimmunol.166.6.3915.

38. Hananantachai H, Patarapotikul J, Ohashi J, Naka I, Krudsood $\mathrm{S}$, Looareesuwan S, et al. Significant association between TNFalpha (TNF) promoter allele $(-1031 \mathrm{C},-863 \mathrm{C}$, and $-857 \mathrm{C})$ and cerebral malaria in Thailand. Tissue Antigens. 2007;69(3):27780. 17493155. Available from: 10.1111/j.1399-0039.2006 00756.x.

39. Huang YC, Chang WC, Shan YH, Lin CY, Wang CL, Dai CY, et al. Toxic Metals Increase Serum Tumor Necrosis Factor- $\alpha$ Levels, Modified by Essential Elements and Different Types of Tumor Necrosis Factor- $\alpha$ Promoter Single-nucleotide Polymorphisms. Epidemiology. 2017;28:113-20. 29028684. Available from: 10.1097/EDE.0000000000000738.

40. Kroeger KM, Carville KS, Abraham LJ. The -308 tumor necrosis factor- $\alpha$ promoter polymorphism effects transcription. Mol Immunol. 1997;34(5):391-9. 9293772. Available from: 10 . 1016/S0161-5890(97)00052-7.

41. Brinkman BM, Zuijdeest D, Kaijzel EL, Breedveld FC, Verweij CL. Relevance of the tumor necrosis factor alpha (TNF alpha) -308 promoter polymorphism in TNF alpha gene regulation. J Inflamm. 1995-1996;46(1):32-41. 8832970.

42. Uglialoro AM, Turbay D, Pesavento PA, Delgado JC, McKenzie $\mathrm{FE}$, Gribben JG, et al. Identification of three new single nucleotide polymorphisms in the human tumor necrosis factoralpha gene promoter. Tissue Antigens. 1998;52(4):359-67. 9820599. Available from: 10.1111/j.1399-0039.1998.tb03056.x.

43. Cui G, Wang H, Li R, Zhang L, Li Z, Wang Y, et al. Polymorphism of tumor necrosis factor alpha (TNF-alpha) gene promoter, circulating TNF-alpha level, and cardiovascular risk factor for ischemic stroke. J Neuroinflammation. 2012;9(1):235. 23050663. Available from: 10.1186/1742-2094-9-235.

44. Kimura K, Takayanagi R, Yokoyama H, Yamada Y. Effects of tumor necrosis factor $\alpha-857 \mathrm{C} / \mathrm{T}$ polymorphism on the expression of tumor necrosis factor $\alpha$. APMIS. 2016;124(8):669-74. 27307133. Available from: 10.1111/apm.12559.

45. Higuchi T, Seki N, Kamizono S, Yamada A, Kimura A, Kato $\mathrm{H}$, et al. Polymorphism of the $5^{\prime}$-flanking region of the human tumor necrosis factor (TNF)- $\alpha$ gene in Japanese. Tissue Antigens. 1998;51(6):605-12. 9694352. Available from: 10.1111/j.1399-0039.1998.tb03002.x. 